\title{
RUANG BUDAYA “BARIKAN” DI DESA \\ SUMBER POLAMAN LAWANG JAWA TIMUR
}

\author{
Fifi Damayanti¹, Agung Murti Nugroho² ${ }^{2}$ Herry Santosa²
}

\begin{abstract}
${ }^{1}$ Mahasiswa Program Magister Arsitektur Lingkungan Binaan/ Fakultas Teknik, Universitas Brawijaya Malang ${ }^{2}$ Dosen Program Magister Arsitektur Lingkungan Binaan/ Fakultas Teknik, Universitas Brawijaya Malang ${ }^{2}$ Dosen Program Magister Arsitektur Lingkungan Binaan/ Fakultas Teknik, Universitas Brawijaya Malang
\end{abstract}

\author{
fifidamayanti197408@yahoo.co.id
}

\begin{abstract}
ABSTRAK
Kota Lawang mempunyai banyak tempat wisata menarik, salah satunya yaitu Pemandian Sumber Polaman, yang terletak di Desa Sumber Polaman. Pada Desa Sumber Polaman tersebut terdapat beberapa aktivitas budaya masyarakat yang membentuk ruang budaya. Masyarakat setempat melakukan upacara adat ritual desa untuk menghormati arwah leluhur pendiri desa serta sebagai permohonan kepada Tuhan untuk kemakmuran masyarakat desa Polaman. aktivitas budaya tersebut dikenal sebagai ritual budaya barikan. Waktu dan. ruang pada ritual Barikan membentuk pola permukiman tradisional masyarakat desa Polaman. Metode penelitian yang dilakukan pada penelitian ini adalah Metode deskriptif-kualitatif dengan pendekatan etnografi. Penelitian ini bertujuan untuk mengidentifikasi pola permukiman yang terbentuk akibat dari adanya aktivitas budaya yang membentuk ruang budaya. Dengan mengetahui pola permukiman yang terbentuk maka akan dapat ditentukan bentuk pelestarian yang cocok bagi ruang-ruang permukiman yang digunakan maupun pelestarian budaya barikan itu sendiri.
\end{abstract}

Kata Kunci: ruang budaya, upacara adat barikan, Desa Sumber Polaman

\begin{abstract}
Lawang city has many interesting sights, one of which is the source Polaman Baths, located in Sumber Polaman. In the Village of Polaman there are some cultural activities that make up the cultural space. Local communities do village ritual ceremonies to honor ancestors founders of the village as well as a petition to God for the prosperity of rural communities Polaman. The cultural activities are known as cultural ritual barikan. Time and Barikan ritual space in the traditional settlement pattern forming Polaman rural communities. The research method in this study is descriptive-qualitative method with an etnographic approach. This study aims to identify patterns formed by the settlement of the cultural activities that make up the cultural space. By knowing the settlement pattern is formed it will be determined the shape of preservation suitable for spaces used settlements and cultural preservation barikan itself.
\end{abstract}

Keywords: cultural space, barikan traditional ceremonies, village Source Polaman

\section{Pendahuluan}

\subsection{Sejarah Pembentukan Kawasan}

Lawang (pintu), adalah sebuah kecamatan di Kabupaten Malang, Jawa Timur. Kecamatan ini merupakan salah satu dari 33 kecamatan yang ada di Kabupaten Malang. Kecamatan ini berbatasan langsung dengan:
1. Sebelahutara : Kabupaten Pasuruan
2. Sebelahtimur : Kecamatan Jabung
3. Sebelahselatan : Kecamatan Singosari
4. Sebelahbarat : KecamatanSingosari 
Kecamatan ini menjadi "pintu masuk" atau kota pembuka bagi Kabupaten Malang dari arah Kota Surabaya. Kondisi geografis Kecamatan Lawang termasuk daerah pegunungan dan dikelilingi Gunung Arjuno dan Gunung Semeru. Kecamatan Lawang berbatasan dengan Kecamatan Singosari, Kabupaten Malang dan Kecamatan Purwodadi, Kabupaten Pasuruan. Lawang $19 \mathrm{~km}$ di sebelah utara Kota Malang, atau $71 \mathrm{~km}$ di sebelah selatan Kota Surabaya Propinsi Jawa Timur.

Keberadaan Kota Lawang dalam catatan sejarah nampaknya sudah dimulai sejak lama, yaitu sejak jaman Kerajaan Majapahit diperintah oleh Raja Hayam Wuruk. Raja sering mengadakan perjalanan kenegaraan meninjau daerah-daerah wilayah Majapahit, disertai para pembesar kerajaan. Nagarakertagama (sebuah karya sastra yang menceritakan tentang perjalanan Hayam Wuruk ke sejumlah wilayah di Jawa Timur) merupakan karya sastra yang menyebut sejumlah wilayah yang berdasar hasil identifikasi adalah berada di Kecamatan Lawang sekarang.

Setelah melakukan perjalanan selama 2 bulan, Raja Hayam Wuruk memutuskan pulang. Perjalanan pulang ini menurut Sidomulyo (2007) mengambil arah utara (dari ibukota Singhasari masa itu), melalui Banu Hanget, Banir dan Talijungan, sampai di Wedhwa-wedwan, tempat bermalam rombongan Raja Hayam Wuruk.

Diantara nama-nama daerah tersebut, hanya Wedhwa-wedwan yang dapat diidentifikasikan pada masa sekarang. Kemungkinan posisi Wedhwa-wedwan berada di Bukit Wedon, yang tampak di sebelah barat jalan raya di Desa Turirejo, Kecamatan Lawang, 9 km di sebelah utara Singosari.

Ada kemungkinan Banu Hanget yang menunjukkan sebuah sumber air panas, dapat diidentifikasikan dengan pemandian kuno di Dusun Polaman yang masuk Desa Bedali. Sidomulyo (2007) menguraikan jika kini sumber Polaman hanya mengeluarkan air dingin, tetapi belum tentu begitu pada masa lalu. Di samping itu, di sumber Polaman masih ditemukan peninggalan purbakala berupa batu-batu candi, baik di sekitar pemandian maupun di sebuah gua yang terletak pada jarak $350 \mathrm{~m}$ di sebelah barat laut. Menurut tradisi setempat, gua tersebut bekas pertapaan Ken Arok (Prasasti, 2015).

\subsection{Lokasi Studi}

Tempat penelitian berada di Desa Polaman, Kecamatan Lawang, Kabupaten Malang, Jawa Timur. Tempat ini terletak di Jalan Indrokilo, Dusun Polaman, Desa Kalirejo, Lawang, Kabupaten Malang yang berada sekitar $5 \mathrm{~km}$ ke arah barat dari Pasar Lawang atau dari jalan raya Malang-Surabaya. Desa Polaman berada di ketinggian 500-560 meter dpl (dari permukaan laut) dengan suhu rata-rata 23-32C dan curah hujan rata-rata $349 \mathrm{~mm} / \mathrm{tahun}$. Desa Polaman memiliki luas 30 hektar, desa ini masuk wilayah RW 10 Kelurahan Kalirejo yang meliputi 4 RT, yaitu RT 01, RT 02, RT 03, RT 04, dengan jumlah kepala keluarga sebanyak 257 KK. Jumlah penduduk desa Polaman RW 10 sebanyak 897 jiwa, dengan jumlah warga laki-laki 445 orang dan warga perempuan 452 orang (Laporan Pertanggungjawaban Ketua RW 10 Kelurahan Kalirejo Kec Lawang, 2016).

Batas Desa Polaman:

1. Sebelah utara

2. Sebelah timur

3. Sebelah selatan

4. Sebelah barat

: Desa Karangsono (Kelurahan Kalirejo)

: Desa Bedali (Kelurahan Bedali)

: Desa Bedali (Kelurahan Bedali)

: Desa Sumber Mlaten (Kelurahan Kalirejo) 

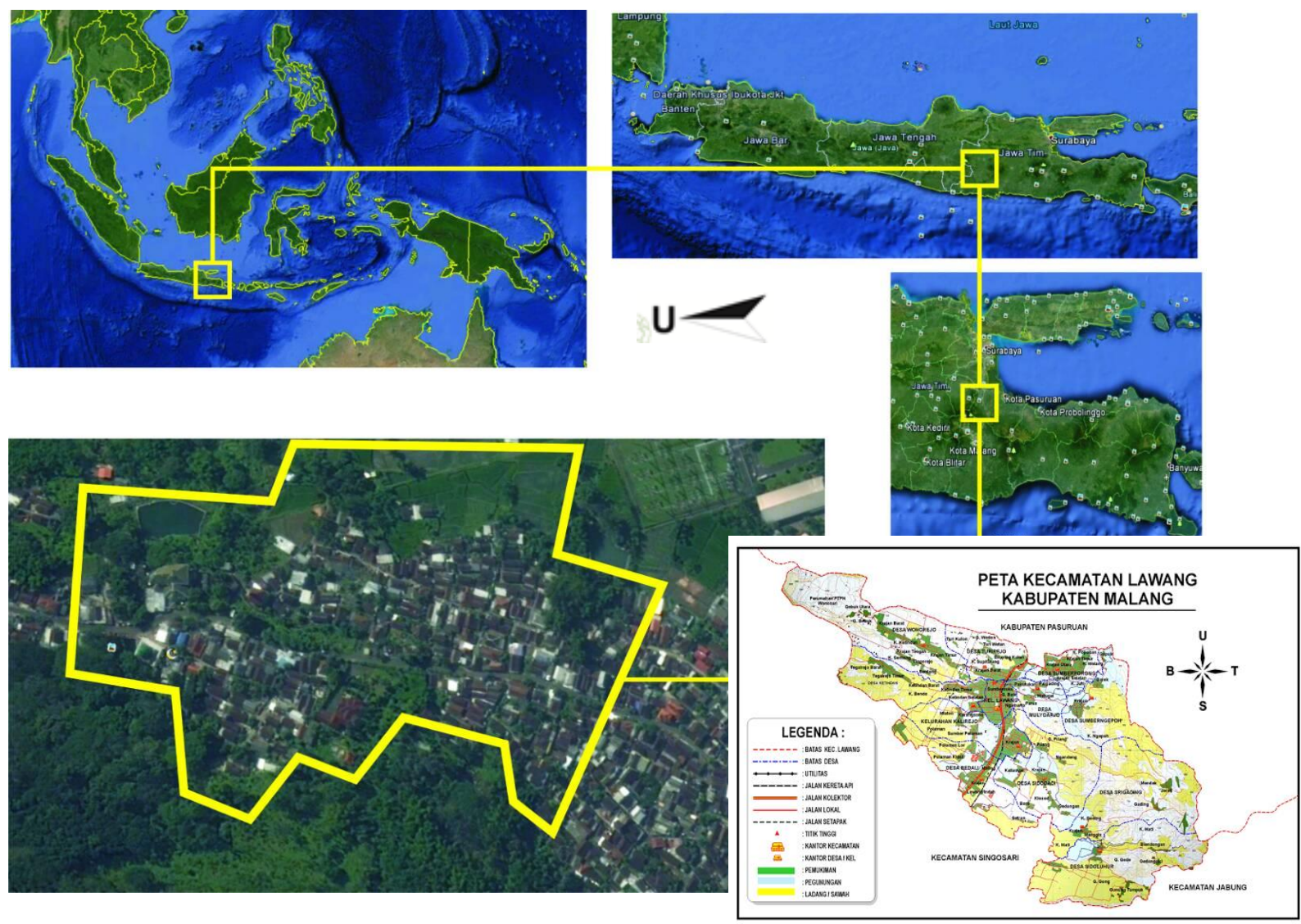

Gambar 1. Peta Lokasi Studi

Sumber: Google Maps, 2015

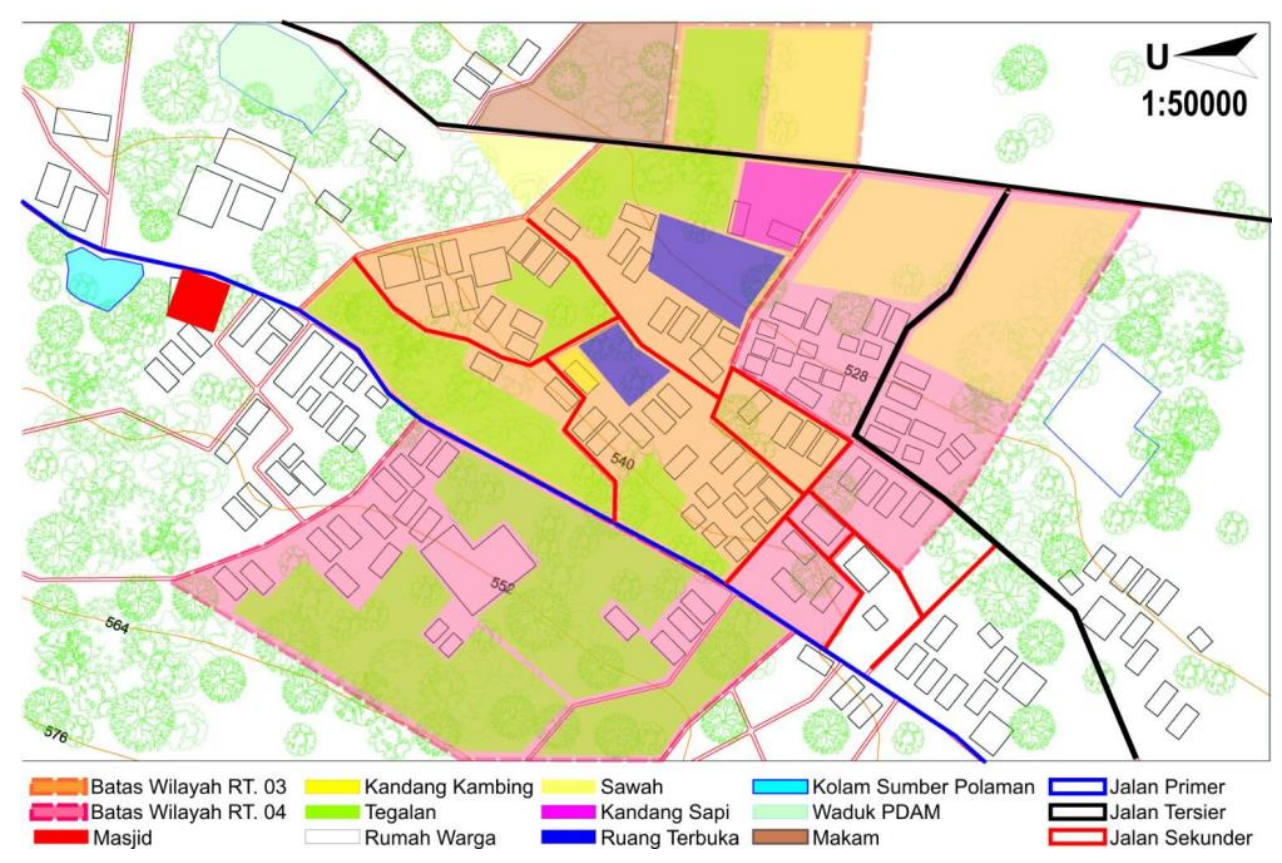

Gambar 2. Peta Persil Wilayah Desa Polaman Lawang Sumber: Data yang diolah dari Google Maps, 2015

Terbentuknya kampung-kampung di desa Polaman Lawang biasanya dimulai dari sekelompok orang yang membentuk suatu desa kecil yang kemudian semakin lama kian sempurna. Kawasan ini dibentuk dan dipengaruhi oleh faktor-faktor alami kawasan dan 
ekspresi fisik serta budaya yang telah diwariskan secara turun temurun. Faktor-faktor tersebut membentuk zonasi kehidupan tradisional yang harus tetap dijaga untuk mendukung kelestarian kawasan tersebut.
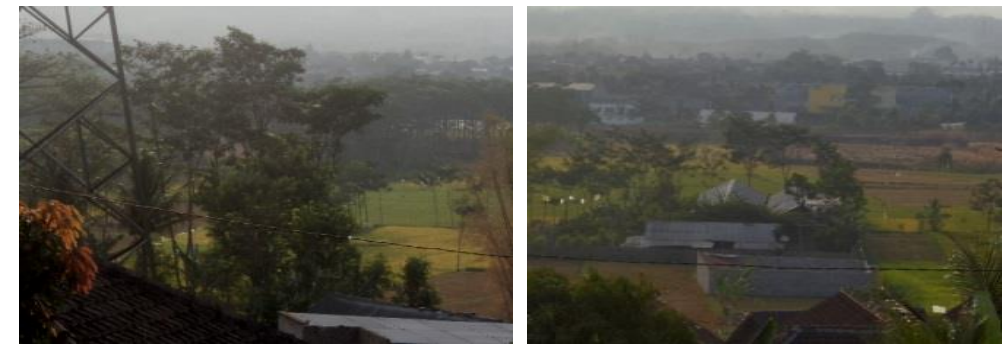

Gambar 3. Bentuk Fisik dari Permukiman Desa Polaman Lawang Mencirikan Permukiman Perdesaan

Sumber: Dokumentasi Pribadi, 9 Oktober 2015

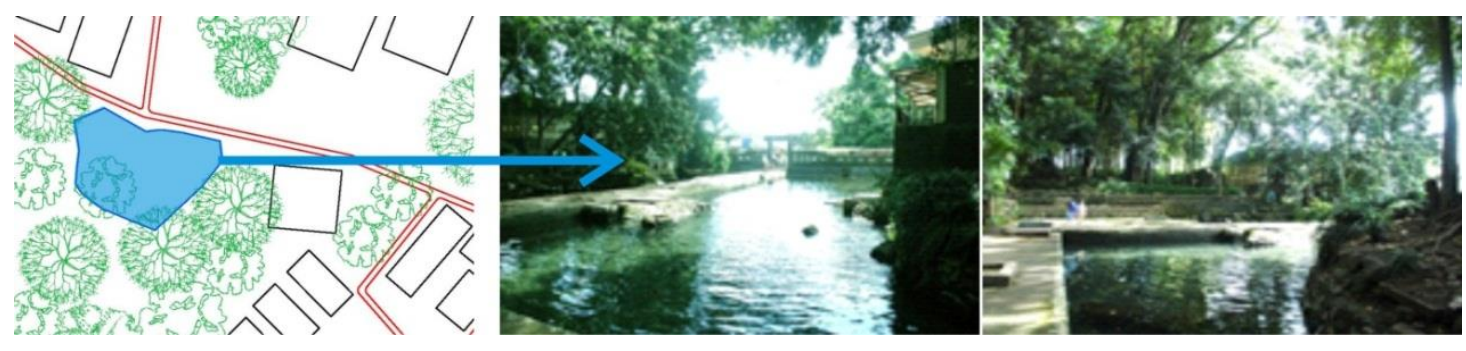

Gambar 4. Peta Lokasi Kolam Pemandian Polaman

Sumber: Badan Kordinasi Survey dan Pemetaan Nasional (Bakosurtanal)

Polaman mempunyai 3 kolam utama dan beberapa deretan arca peninggalan masa lampau yang dipasang rapi di daerah barat dari pemandian, tujuannya untuk diperlihatkan pada pengunjung agar dapat dipelajari oleh generasi penerus kita. Di kanan-kiri sumber air berupa kolam-kolam untuk pemandian anak-anak, kolam masjid, tempat pemeliharaan ikan dan teratai.

Kolam yang biasa dipakai untuk mandi atau berenang berada di depan, di sebelah selatan, sementara kolam utara dan kolam barat penuh dengan ikan-ikan yang membuat kolam tersebut tidak memungkinkan digunakan untuk kepentingan berenang (Putro, 2014).
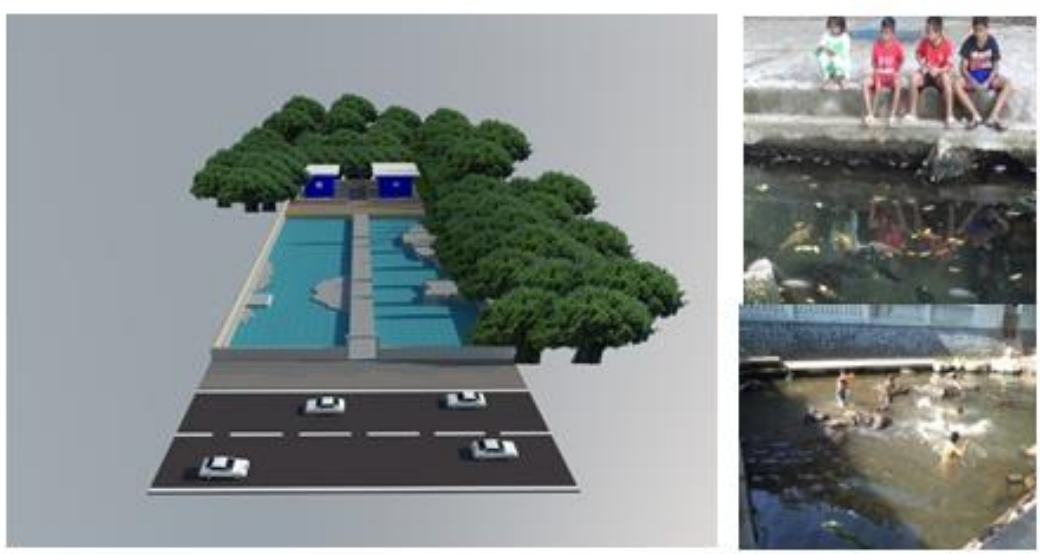

Gambar 5. Anak-anak Bermain di Tepi Kolam Pemandian Polaman Sebelah Utara Sumber: Dokumentasi Pribadi, 9 Oktober 2015 


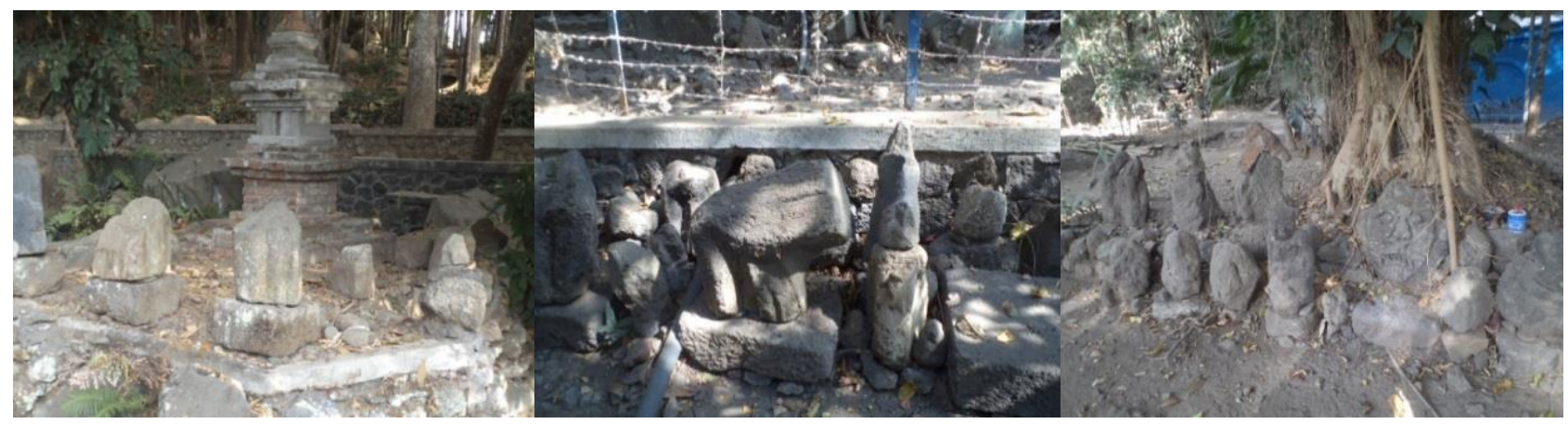

Gambar 6. Foto Deretan Arca Peninggalan Purbakala di Bawah Pohon Tua Sebelah Barat Kolam Pemandian Polaman

Sumber: Dokumentasi Pribadi, 9 Oktober 2015

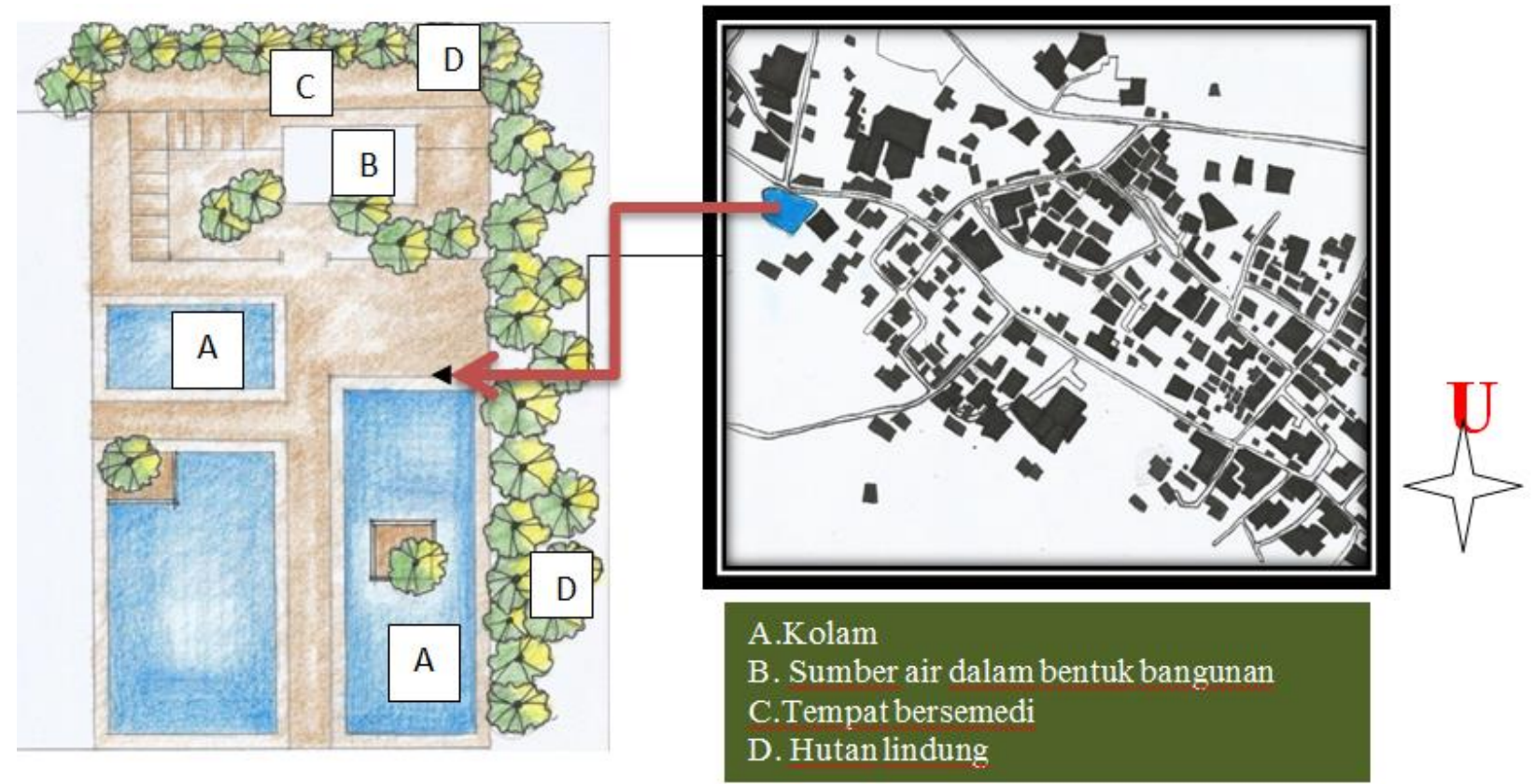

Gambar 7. Peta Lokasi Kawasan Kolam Pemandian Polaman Sumber: Google Maps, 2015

\section{Bahan dan Metode}

\section{$2.1 \quad$ Ruang}

Suatu permukiman merupakan wujud interaksi antara manusia dengan lingkungan sekitarnya. Laurens dalam Yuanita, et al., menyatakan bahwa manusia dan lingkungan saling mempengaruhi karena lingkungan bukan hanya sebagai wadah manusia beraktivitas, namun juga merupakan bagian integral dari pola perilaku manusia. Salah satu bentuk permukiman adalah permukiman tradisional. Permukiman ini sering direpresentasikan sebagai tempat yang masih memegang nilai-nilai adat dan budaya yang dihubungkan dengan nilai-nilai kepercayaan atau agama yang bersifat khusus atau unik pada masyarakat tertentu yang berakar dari tempat tertentu pula di luar determinasi sejarah (Crysler dalam Sasongko, 2005). Terbentuknya hunian karena adanya proses pembentukan hunian sebagai wadah fungsional yang dilandasi oleh pola aktivitas manusia serta pengaruh setting rona lingkungan, baik yang bersifat fisik maupun nonfisik yang mempengaruhi pola kegiatan dan proses pewadahannya.

Salah satu perwujudan hasil adaptasi manusia adalah adanya penggunaan ruang-ruang permukiman dalam menjalankan aktivitasnya. Hal ini terjadi karena ruang adalah sesuatu 
yang bisa diisi. Ruang tidak ada dengan sendirinya, tetapi ada proses pembentukannya yang diakibatkan oleh faktor sosial, demografi, ekonomi dan lain sebagainya (Indeswari, et al., 2013). Penggunaan ruang dan wujud arsitektur suatu daerah merupakan bagian dari masyarakat dengan budayanya pada lingkungan alamnya (Ardianti, et al., 2014).

Struktur ruang permukiman digambarkan melalui pengidentifikasian tempat, lintasan, dan batas sebagai komponen utama, selanjutnya diorientasikan melalui hirarki dan jaringan atau lintasan. Yang muncul dalam lingkungan binaan mungkin secara fisik atau non fisik. Untuk membentuk struktur ruang tidak hanya orientasi yang terpenting, tetapi juga objek nyata dari suatu identifikasi (Norberg-Schulz, 1979). Dalam suatu lingkungan tempat suci berfungsi sebagai pusat yang selanjutnya menjadi orientasi dan identifikasi bagi manusia, dan merupakan struktur ruang (Norberg-Schulz, 1979).

Teori ruang permukiman tidak dapat dipisahkan dari kosmologi, dimana filosofi ruang dipengaruhi oleh macro cosmos dan micro cosmos. Dalam masyarakat tradisional, rumah merupakan miniatur dari alam semesta. Konsep kosmologi inilah yang akhirnya melahirkan aktivitas atau ritual-ritual dalam masyarakat. Arsitektur rumah tradisional mengutamakan proses pembentukan yang mana sasaran pembentukannya lebih menekankan pada proses terbentuknya berdasarkan ritual agama dan kepercayaan (Rapoport, 1969).

Elemen dasar pendekatan dan pemahaman terhadap pola penggunaan ruang menurut Rapoport (1997), yaitu sebagai berikut:

1. KegiatanManusia, Ruang kegiatan manusia (home range) merupakan batas-batas umum terdiri dari beberapa setting atau lokasi, serta jaringan penghubung antar lokasi mempunyai radius home range tertentu yang dapat diklasifikasikan menjadi home range harian, mingguan dan bulanan.

2. Area Inti (Core Inti), Merupakan area ruang kegiatan manusia yang paling sering dipakai, dipahami dan langsung dikontrol oleh penduduk. Dalam konteks ini lingkungan area inti merupakan lingkungan-lingkungan perumahan dengan isitem sosial yang relatif kental, merupakan cluster-cluster kegiatan yang setiap hari muncul diorganisisr oleh kelompok penduduk yang mengenal secara personal.

3. Teritori, Merupakan area yang erat kaitannya dengan privacy dan personal space, sama dengan personal space, teritorialitas adalah juga perwujudan ego yang tidak ingin diganggu. dengan kata lain merupakan perwujudan privasi. Teritorialitas itu sendiri adalah suatu pola tingkah laku yang ada hubungannya dengan kepemilikan atau hak seseorang atas suatu lokasi

4. Area Terkontrol (Juridiction), Merupakan suatu area yang dikuasai dan dikontrol secara temporer oleh sekelompok penduduk kota. Oleh karena pengusahaannya yang bersifat temporer maka dimungkinkan suatu area dikuasai oleh kelompok yang berbeda

5. Personal Distance/Space (Ruang Personal), Merupakan suatu jarak atau area dengan intervensi oleh orang lain akan terasa menggangu, berbeda dengan keempat elemen tersebut di atas yang cenderung fisikal batasnya, personal distance biasanya tidak mempunyai kenampakan fisik yang jelas.

Dengan demikian sebagai wujud fisik, kebudayaan merupakan hasil kompleks gagasan yang tercermin dalam pola aktivitas masyarakatnya.

Struktur ruang permukiman digambarkan melalui pengidentifikasian tempat, lintasan, dan batas sebagai komponen utama, selanjutnya diorientasikan melalui hirarki dan jaringan atau lintasan. Yang muncul dalam lingkungan binaan mungkin secara fisik atau non fisik. Untuk membentuk struktur ruang tidak hanya orientasi yang terpenting, tetapi juga objek nyata dari suatu identifikasi (Norberg-Schulz, 1979). Dalam suatu lingkungan tempat suci berfungsi sebagai pusat yang selanjutnya menjadi orientasi dan identifikasi bagi manusia, dan merupakan struktur ruang (Norberg-Schulz, 1979). 


\subsubsection{Kebudayaan}

Rapoport (1977) menyampaikan bahwa setiap kelompok masyarakat mempunyai cara tersendiri untuk menjalankan proses yang tepat dalam menjalin hubungan kebersamaan dalam kehidupan masyarakat. Rapoport (1969) juga menyatakan bahwa kebudayaan adalah merupakan suatu kompleks gagasan dan pikiran manusia bersifat tidak teraga. Kebudayaan akan terwujud melalui pandangan hidup, tata nilai, gaya hidup dan aktivitas yang bersifat konkrit. Aktivitas ini secara langsung akan mempengaruhi wadah, yakni lingkungan yang diantaranya adalah ruang-ruang di dalam permukiman.

Dalam konteks budaya berkait dengan ruang permukiman, Yi-Fu Tuan (1977) menyatakan untuk menjelaskan makna dari organisasi ruang dalam konteks tempat (place) dan ruang (space) harus dikaitkan dengan budaya. Budaya sifatnya unik, antara satu tempat dengan tempat lain bisa sangat berbeda maknanya. Selanjutnya manusia akan mengekspresikan dirinya pada lingkungan dimana dia hidup, sehingga lingkungan tempat tinggalnya akan diwujudkan dalam berbagai simbolisme sesuai dengan budaya mereka. Bagaimana manusia memilih tempat tertentu dan menggunakan berbagai kelengkapan, ataupun berbagai cara untuk berkomunikasi pada dasarnya merupakan "bahasa" manusia.

Aktivitas budaya yang terlihat dalam ritual-ritual masyarakat, baik ritual budaya maupun religi akan selalu mempengaruhi pola permukiman masyarakatnya. Pola permukiman yang dipengaruhi dapat berupa struktur bentukan permukimannya atau juga nilai ruang huniannya. Rapoport (1969) juga menyatakan bahwa kebudayaan adalah merupakan suatu kompleks gagasan dan pikiran manusia bersifat tidak teraga. Kebudayaan akan terwujud melalui pandangan hidup, tata nilai, gaya hidup dan aktivitas yang bersifat konkrit. Aktivitas ini secara langsung akan mempengaruhi wadah, yakni lingkungan yang diantaranya adalah ruang-ruang di dalam permukiman.

\subsubsection{Ritual Barikan di Desa Polaman}

Barikan adalah aktivitas sosial budaya dimana masyarakat makan bersama yang dilakukan di tempat terbuka, biasanya di halaman atau tempat-tempat tertentu yang disakralkan dalam suatu masyarakat. Dalam acara Barikan pada umumnya tumpeng dibagi dalam wadah daun pisang lalu makan bersama-sama. Barikan bertujuan untuk merukunkan, mengakrabkan, membina perasaan bersatu/guyub dalam kelompok. Barikan bisa juga berfungsi untuk mendamaikan pihak yang bertikai.

Pemandian Sumber Polaman bermata air dari Gunung Arjuno dan berada di tepi jalan desa. Selain sebagai pemandian, di sekitar tempat itu juga sering dipergunakan untuk kegiatan perkemahan dan outbound.

Menurut cerita yang berkembang di masyarakat, kata Polaman berasal dari kata "paulaman" yang berarti tempat memelihara ikan Pada masa sekarang sumber air ini dijadikan tempat memelihara ikan, baik yang ikan yang disakralkan secara turun temurun yaitu ikan 'wader' (sejenis hemipiraclodus borneensia) dan beberapa jenis ikan yang lain. Menurut kepercayaan masyarakat, setiap orang tidak boleh menangkap ikan wader apalagi sampai menggorengnya. Kalau hal tersebut dilakukan, orang yang bersangkutan akan mendapatkan petaka. Oleh sebab itu ia harus mengembalikan ke tempat semula atau meminta maaf kepada penunggu mata air. Adapun asal muasal ikan tersebut adalah peliharaan Mbah Jayadursa. Jayadursa adalah tokoh cikal bakal dukuh Polaman. Makam Jayadursa berada di makam desa dan setiap hari Jum'at Legi diadakan acara ritual "Barikan" dengan tujuan supaya desa Polaman selalu makmur dan dijauhkan dari segala bencana. 


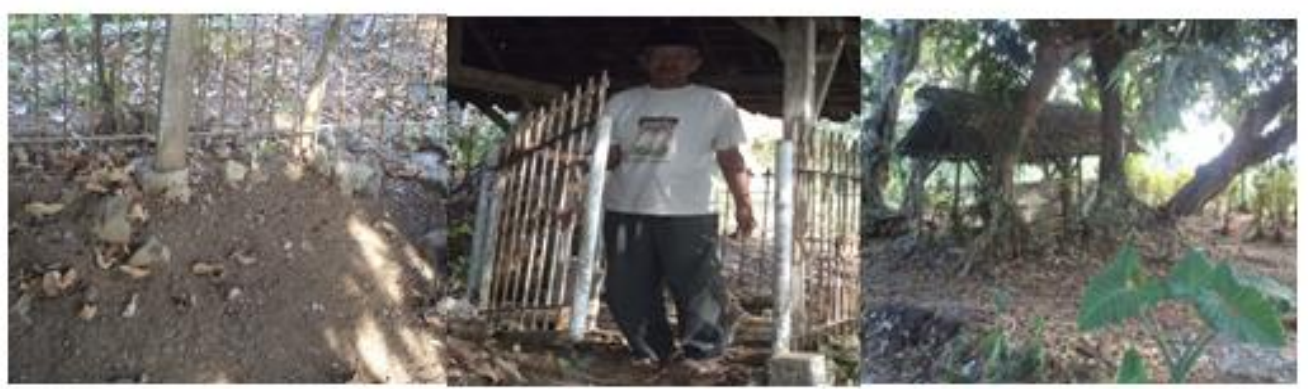

Gambar 8. Makam Mbah Wuning (Istri dari Mbah Direkso) Berada di makam Karang Suwung Sumber: Dokumentasi Pribadi, 9 Oktober 2015
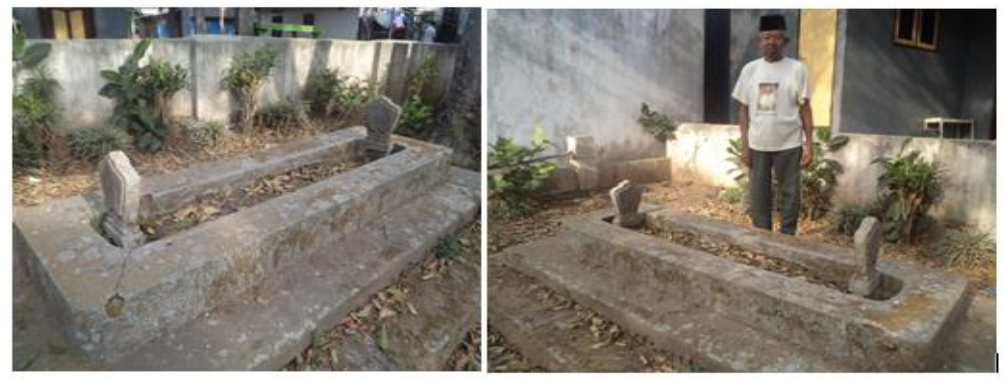

Gambar 9. Makam Jayadursa (Mbah Direkso) Terletak di Pinggir Jalan Indrokilo Barat Sumber: Dokumentasi Pribadi, 9 Oktober 2015

Pada bulan September diadakan tradisi bersih desa, suatu ritual desa untuk mengenang dan menghormati arwah leluhur desa sebagai pendiri desa. Upacara adat ini dilakukan secara gotong royong untuk membersihkan desa. Pada malam-malam tertentu, di tempat sumber air banyak digunakan orang untuk bersemedi atau melakukan ritual tertentu dengan maksud tertentu (lelaku) sambil memberi makan ikan yang hidup di mata air dan menyediakan sarana sesaji yang berisi daun sirih dan biji pinang (bumbu kinang). Apabila keinginannya terkabulkan, ia akan kembali dan menggelar kenduri untuk makan bersama warga sekitar (Wurianto, 2009).

\subsection{Metode Penelitian}

Berdasarkan bidang ilmu yang mendasari menurut Wasito (1992), penelitian yang akan dilakukan termasuk dalam penelitian sosial. Hal ini dikarenakan topik yang ingin dikaji dalam penelitian ini adalah mengenai ruang budaya Barikan sebagai pembentuk pola permukiman di Desa Polaman. Menurut Nasir (1999), penelitian dalam ilmu sosial dapat disebut sebagai suatu proses yang terus-menerus, kritis, terorganisasi untuk mengadakan analisis dan memberikan interpretasi terhadap fenomena sosial yang memiliki hubungan saling mengait. Pada tradisi Barikan, kaitannya tidak hanya pada aspek sosiokulturalnya saja tetapi juga pola peruangannya.

Selain itu jika dilihat berdasarkan metode yang digunakan maka penelitian mengenai tradisi Barikan di Desa Polaman masuk dalam penelitian kualitatif. Objek pengamatan adalah masyarakat desa Polaman yang masih melaksanakan ritual atau tradisi Barikan, dengan variabel pengamatan berupa perilaku, budaya, dan pola peruangan dari tradisi Barikan itu sendiri. Hal ini sejalan dengan Moleong mengenai penelitian kualitatif. Menurutnya penelitian kualitatif adalah penelitian yang bermaksud untuk memahami fenomena tentang apa yang dialami oleh subjek penelitian misalnya, perilaku, persepsi, motivasi, dan tindakan secara 
holistik dengan cara deskripsi dalam bentuk kata-kata dan bahasa pada suatu konteks khusus yang dialamiahkan dengan cara memanfaatkan berbagai metode ilmiah.

Pada pendekatan kualitatif memuat tentang prosedur penelitian yang menghasilkan data deskriptif berupa kata-kata tertulis atau lisan dari objek dan perilaku yang dapat diamati. Ada beberapa alasan peneliti yang dapat dikemukakan berkaitan dengan penggunaan pendekatan dan jenis penelitian kualitatif (deskriptif), diantaranya:

Pertama, individu-individu yang di dalam menghadapi lingkungan sosialnya, memiliki strategi bertindak yang tepat bagi dirinya sendiri, sehingga memerlukan pengkajian yang mendalam. Penelitian kualitatif memberikan peluang bagi pengkajian mendalam terhadap suatu fenomena.

Kedua, penelitian tentang keyakinan, kesadaran, dan tindakan individu di dalam masyarakat sangat memungkinkan menggunakan penelitian kualitatif karena yang dikaji adalah fenomena yang tidak bersifat eksternal dan berada di dalam diri masing-masing individu.

Ketiga, penelitian kualiatif memberikan peluang untuk meneliti fenomena secara holistik. Fenomena yang dikaji merupakan suatu kesatuan yang tak terpisahkan karena tindakan yang terjadi di kalangan masyarakat (subjek penelitian) bukanlah tindakan yang diakibatkan oleh satu dua faktor melainkan melibatkan banyak faktor yang saling terkait.

Keempat, penelitian kualitatif lebih didasarkan pada pendekatan emik dengan memahami fenomena dari sudut pandang subjek (informan) penelitan setempat (from the native points of view).

\subsubsection{Strategi Penelitian}

Karena penelitian yang dilakukan lebih menekankan pada ruang budaya yang terbentuk pada tradisi Barikan di Desa Polaman maka pendekatan yang sesuai adalah etnografi. Hal ini peneliti lakukan merujuk pada pendapat Cresswell (2012) yang menyatakan bahwa pendekatan etnografi digunakan untuk mempelajari aspek budaya, sosial, dan perilaku (seseorang maupun kelompok masyarakat) dalam suatu setting natural. Aspek budaya yang diamati adalah tradisi Barikan, dimana setting natural yang digunakan adalah Desa Polaman. Penelitian etnografi adalah strategi yang paling sesuai untuk mempelajari dan menggambarkan pola budaya suatu kelompok masyarakat tertentu dengan cara melakukan pengamatan kelompok tersebut dalam setting-nya.

Landasan teori etnografi yang juga dapat digunakan adalah pendapat dari Wolcott (1997) dimana ia menyatakan bahwa etnografi adalah suatu metode khusus atau satu set metode yang didalamnya terdapat berbagai bentuk yang mempunyai karakteristik tertentu, memahami dan mengikuti kehidupan sehari-hari dari seseorang dalam periode yang lama, melihat apa yang terjadi, mendengarkan apa yang dikatakan, bertanya kepada mereka, dan pada kenyataannya mengumpulkan data apa saja yang ada (Wolcott dalam Cresswell, 2012)

\subsubsection{Langkah-langkah Penelitian}

Adanya ketertarikan terhadap fenomena aktivitas tradisonal Barikan yang masih dilestarikan masyarakat di Desa Polaman, Lawang menjadi awal proses kajian. Aktivitas tradisional tersebut membentuk pola peruangan pada kegiatan Barikan tersebut. Pola peruangan yang terbentuk memiliki keunikan tersendiri dan dapat menjadi potensi daerah. Hal-hal itulah yang menjadi latar belakang dilakukannya penelitian ini. Lokasi penelitian merupakan hasil dari studi literatur terhadap penelitian sebelumnya yaitu Aspek Budaya pada Upaya Konservasi Air dalam Situs Kepurbakalaan dan Mitologi Masyarakat Malang yang dilakukan oleh Arif Budi Wurianto (2009).

Langkah selanjutnya adalah melakukan kajian teori baik teori mengenai ruang, maupun mengenai Desa Polaman itu sendiri. Hal ini untuk memberikan landasan berpikir 
secara terstruktur sebelum penelitian dilaksanakan. Adanya landasan teori yang digunakan akan mempersempit ruang penelitian sehingga penelitian akan lebih terfokus pada esensi atau hal yang ingin dikaji.

Kemudian langkah yang ketiga adalah penggunaan metode sampling. Metode sampling ini dilakukan untuk menentukan lokasi, jumlah sampel, dan juga pelaksanaan observasi. Sampling dilakukan karena mustahil untuk melakukan penelitian dengan pendekatan etnografi dimana pengumpulan data didapatkan melalui dokumentasi, wawancara dan observasi terhadap seluruh populasi yang ada di Desa Polaman. Selain itu masyarakat Desa Polaman yang memiliki keberagaman latar belakang, tidak semua masyarakat tersebut melaksanakan tradisi Barikan. Oleh karena itu, metode sampling yang cocok adalah metode Purposive Sampling, dimana sampel yang akan diamati telah ditentukan terlebih dulu dengan dasar bahwa sampel tersebut akan tepat dalam menjawab rumusan masalah.

Proses pengumpulan data yang dilakukan merupakan proses selanjutnya. Data pada penelitian etnografi didapatkan melalui 3 cara yaitu dokumentasi, observasi dan wawancara. Setelah data terkumpul maka dapat dilakukan analisis data. Analisis data yang dilakukan adalah analisis data kualitatif sehingga didapatkan hasil analisis yang dapat menjawab rumusan masalah yang ada di awal. Dan proses yang terakhir adalah menarik kesimpulan.

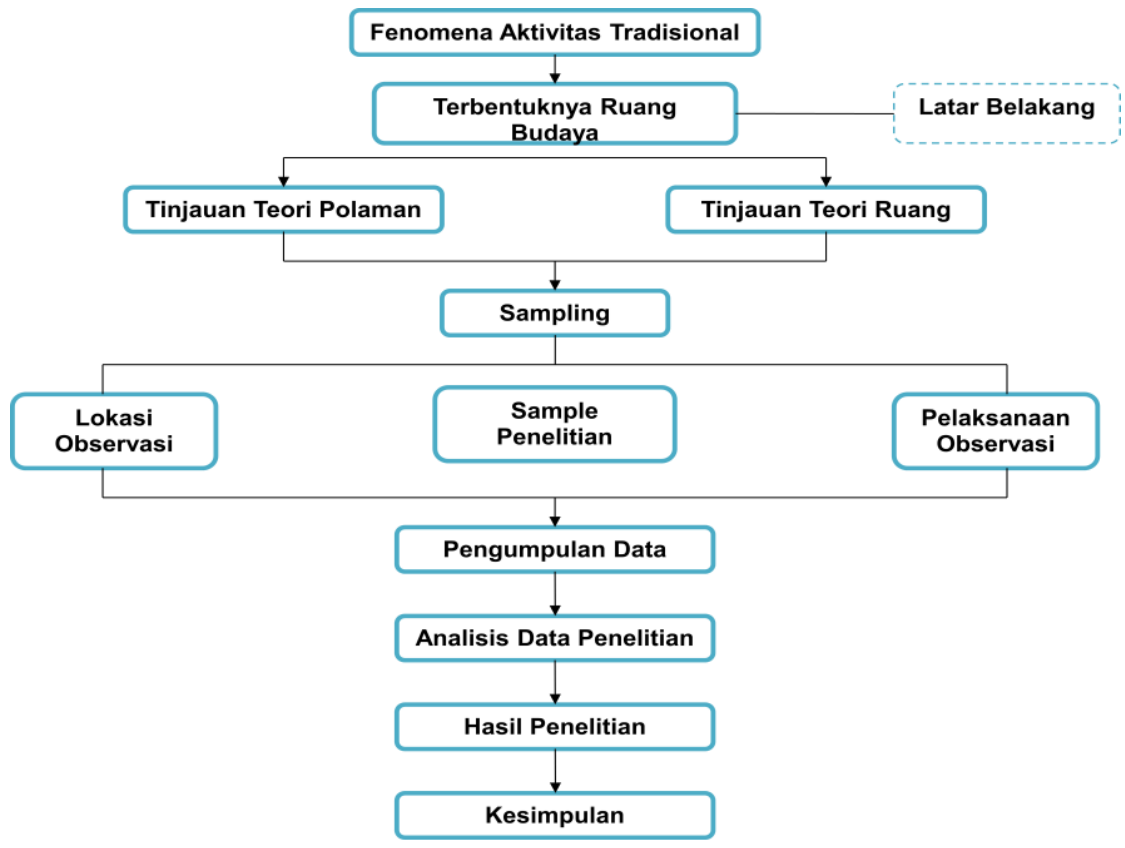

Gambar 10. Diagram Langkah Penelitian

\subsubsection{Taktik Penelitian}

Taktik penelitian dilakukan untuk mengetahui bagaimana cara pengumpulan data yang akurat. Pada penelitian etnografi ada 3 cara pengumpulan data yang umumnya digunakan, yaitu:

1. Dokumentasi

Dokumentasi merupakan catatan peristiwa yang sudah berlalu (Sugiyono, 2008). Dokumentasi seorang peneliti dapat berupa foto, video maupun sketsa. Dokumentasi di dalam penelitian etnografi berfungsi untuk mendukung hasil pengamatan/observasi di lapangan. 


\section{Observasi}

Istilah observasi berasal dan Bahasa Latin yang berarti "melihat" dan "memperhatikan". Istilah observasi diarahkan pada kegiatan memperhatikan secara akurat, mencatat fenomena yang muncul, dan mempertimbangkan hubungan antar aspek dalam fenomena tersebut. Sehingga dapat dikatakan bahwa observasi adalah metode pengumpulan data melalui pengamatan langsung atau peninjauan secara cermat dan langsung di lapangan atau lokasi penelitian. Observasi menjadi bagian dalam penelitian berbagai disiplin ilmu, baik ilmu eksakta maupun ilmu-ilmu sosial. Tujuan observasi adalah untuk memperoleh berbagai data konkret secara langsung di lapangan atau tempat penelitian. Berdasarkan pelaksanaan, observasi dapat dibagi dalam dua jenis, yaitu observasi partisipasi dan observasi non partisipasi.

a. Observasi partisipasi

Observasi partisipasi adalah observasi yang melibatkan peneliti atau observer secara langsung dalam kegiatan pengamatan di lapangan. Jadi, peneliti bertindak sebagai observer, artinya peneliti merupakan bagian dari kelompok yang ditelitinya. Keuntungan cara ini adalah peneliti merupakan bagian yang integral dari situasi yang dipelajarinya sehingga kehadirannya tidak mempengaruhi situasi penelitian. Kelemahannya, yaitu ada kecenderungan peneliti terlampau terlibat dalam situasi itu sehingga prosedur yang berikutnya tidak mudah dicek kebenarannya oleh peneliti lain.

b. Observasi non partisipasi

Observasi non partisipasi adalah observasi yang dalam pelaksanaannya tidak melibatkan peneliti sebagai partisipasi atau kelompok yang diteliti. Cara ini banyak dilakukan pada saat ini. Kelemahan cara ini antara lain kehadiran pengamat dapat mempengaruhi sikap dan perilaku orang yang diamatinya.

Instrumen yang digunakan dalam melakukan observasi, yaitu checklist, rating scale, anecdotal record, catatan berkala, dan mechanical device.

- Check list, merupakan suatu daftar yang berisikan nama-nama responden dan faktorfaktor yang akan diamati.

- Rating scale, merupakan instrumen untuk mencatat gejala menurut tingkatantingkatannya.

- Anecdotal record, merupakan catatan yang dibuat oleh peneliti mengenai kelakuankelakuan luar biasa yang ditampilkan oleh responden.

- Mechanical device, merupakan alat mekanik yang digunakan untuk memotret peristiwa- peristiwa tertentu yang ditampilkan oleh responden.

3. Wawancara

Wawancara merupakan alat rechecking atau pembuktian terhadap informasi atau keterangan yang diperoleh sebelumnya. Teknik wawancara yang digunakan dalam penelitian kualitatif adalah wawancara mendalam. Wawancara mendalam (in-depth interview) adalah proses memperoleh keterangan untuk tujuan penelitian dengan cara tanya jawab sambil bertatap muka antara pewawancara dengan informan atau orang yang diwawancarai, dengan atau tanpa menggunakan pedoman (guide) wawancara, di mana pewawancara dan informan terlibat dalam kehidupan sosial yang relatif lama (Sutopo 2006).

Interview adalah usaha mengumpulkan informasi dengan mengajukan sejumlah pertanyaan secara lisan untuk-dijawab secara lisan pula. Ciri utama dari interview adalah kontak langsung dengan tatap muka (face to face relation ship) antara si pencari informasi (interviewer atau informan hunter) dengan sumber informasi (interviewee) (Sutopo 2006). Wawancara dibedakan menjadi 2 yaitu wawancara tidak terstruktur dan wawancara terstruktur 
Perbedaan kedua jenis wawancara tersebut terletak pada ada atau tidaknya pedoman wawancara yang dibuat oleh seorang peneliti.

Beberapa hal yang perlu diperhatikan seorang peneliti saat mewawancarai responden adalah intonasi suara, kecepatan berbicara, sensitifitas pertanyaan, kontak mata, dan kepekaan nonverbal. Dalam mencari informasi, peneliti melakukan dua jenis wawancara, yaitu autoanamnesa (wawancara yang dilakukan dengan subjek atau responden) dan aloanamnesa (wawancara dengan keluarga responden) (Sugiyono, 2008).

Wawancara yang dilakukan mempunyai dua macam responden yaitu key person dan penduduk. Key person yang dimaksud disini merupakan orang yang memiliki pengetahuan yang mendalam terhadap Desa Polaman, baik mengenai terbentuknya Desa Polaman maupun aktivitas tradisional Barikan. Sedangkan penduduk merupakan responden, dimana hasil wawancara dengan penduduk dilakukan sebagai crossing terhadap informasi yang telah didapatkan dari key person.

\section{Hasil dan Diskusi}

\subsection{Karakteristik Fisik Elemen Pembentuk Kawasan Sumber Polaman Lawang}

Sejalan dengan apa yang dikemukakan oleh Carmona et.al. (2003), kajian morfologi didefinisikan sebagai kajian tentang bentuk dan proses terbentuknya suatu permukiman atau perkampungan. Beberapa elemen pembentuk morfologi ruang, yaitu:

\subsubsection{Land Use (Penggunaan Lahan)}

Pola penggunaan lahan yang terbentuk pada Desa Polaman terdiri dari permukiman, sawah dan hutan. Penggunaan lahan di Desa Polaman masih didominasi oleh lahan sawah dan kebun. Fisik lingkungan di kawasan ini berawal dari perkembangan arsitektur yang dipengaruhi oleh latar belakang masyarakat yang sebagian besar merupakan masyarakat menengah ke bawah dengan penghasilan sehari hari dari hasil pertanian, hasil ternak dan sebagai buruh pabrik.

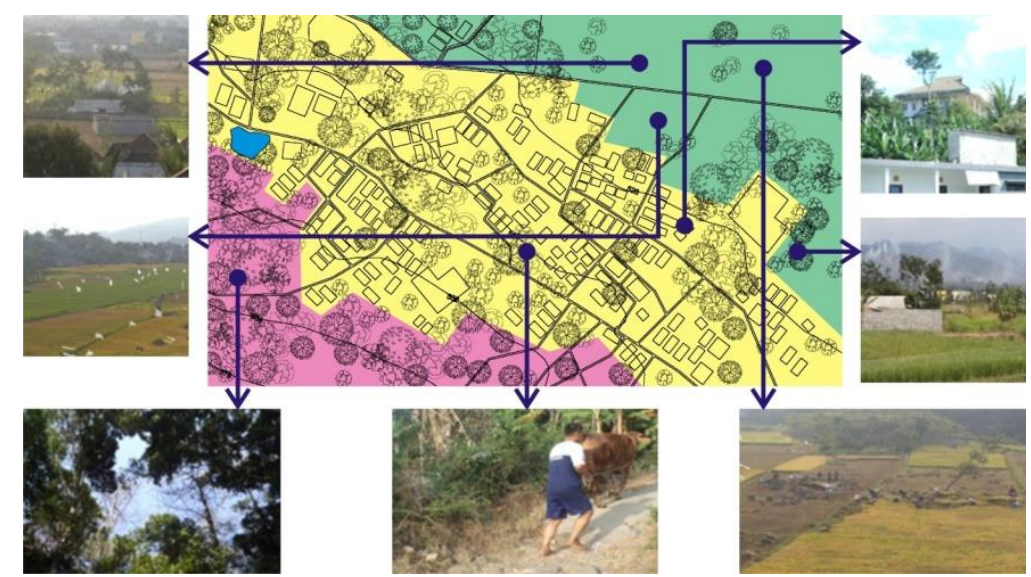

Gambar 11. Aktivitas Warga Sehari-hari sebagai Petani dan Peternak Memanfaatkan Sumber Air/Telaga Polaman sebagai Pengairan Sawah Sumber : Dokumentasi Pribadi, 9 Oktober 2015

Ditinjau dari pola tata guna lahannya, bentuk perdesaan di Polaman Lawang membentuk desa terpusat. Pengertian bentuk desa terpusat yaitu, desa yang banyak dijumpai di wilayah pegunungan. Wilayah pegunungan biasanya dihuni oleh penduduk yang berasal dari keturunan yang sama sehingga antara sesama warga masih merupakan saudara atau kerabat. Hal ini berlaku di Desa Polaman, dimana hubungan kekerabatan antar tetangga sangat kental, karena mereka masih bersaudara. 


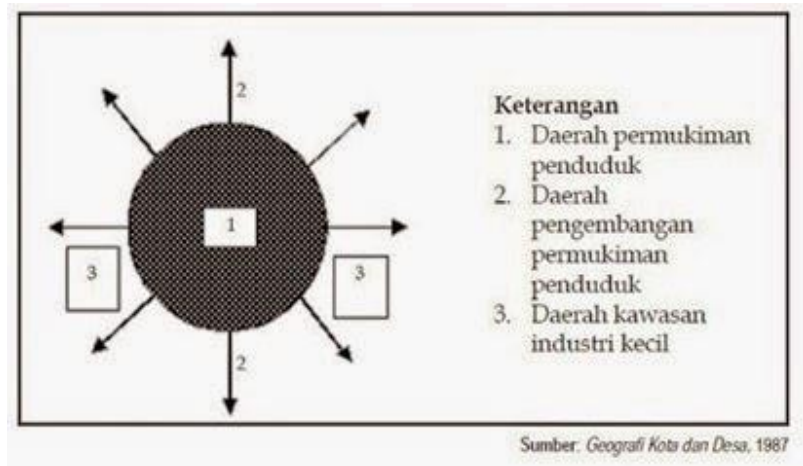

Gambar 12. Bentuk Desa Terpusat

Prasarana pada tingkat sedang mulai memadai, baik kuantitas maupun kualitasnya. Pola tumbuh bangunan tidak beraturan dalam satu lokasi dan tanpa perencanaan. Hal yang demikian akanmuncul gang gang kecil yang selanjutnya menjadi kawasan kampung yang padat.

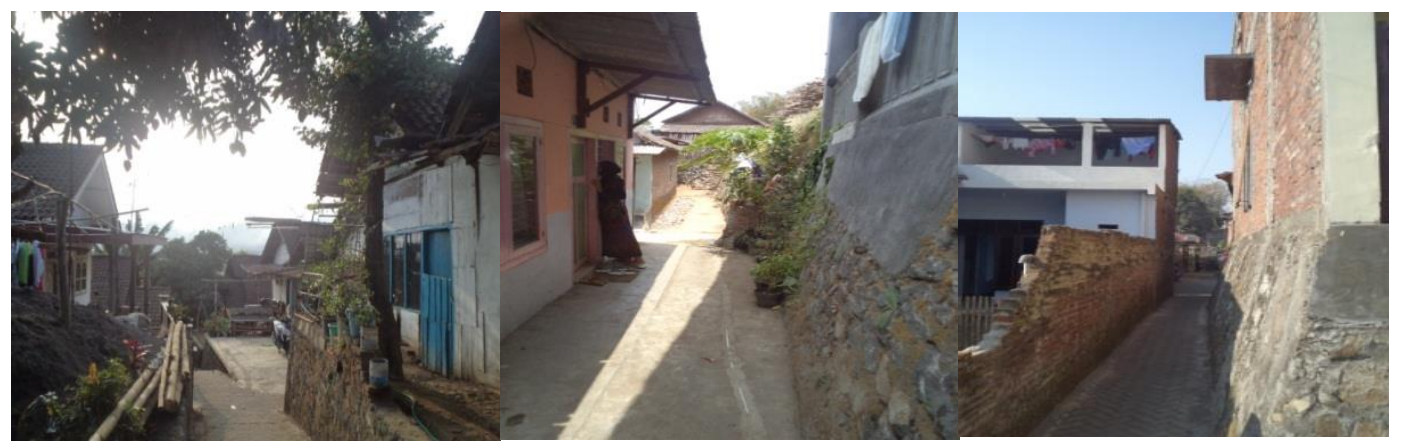

Gambar 13. Kawasan Kampung Padat Penduduk dengan Gang-Gang Kecil Sumber: Dokumentasi Pribadi, 9 Oktober 2015

\subsubsection{Building Structures (Tipe dan Massa Bangunan)}
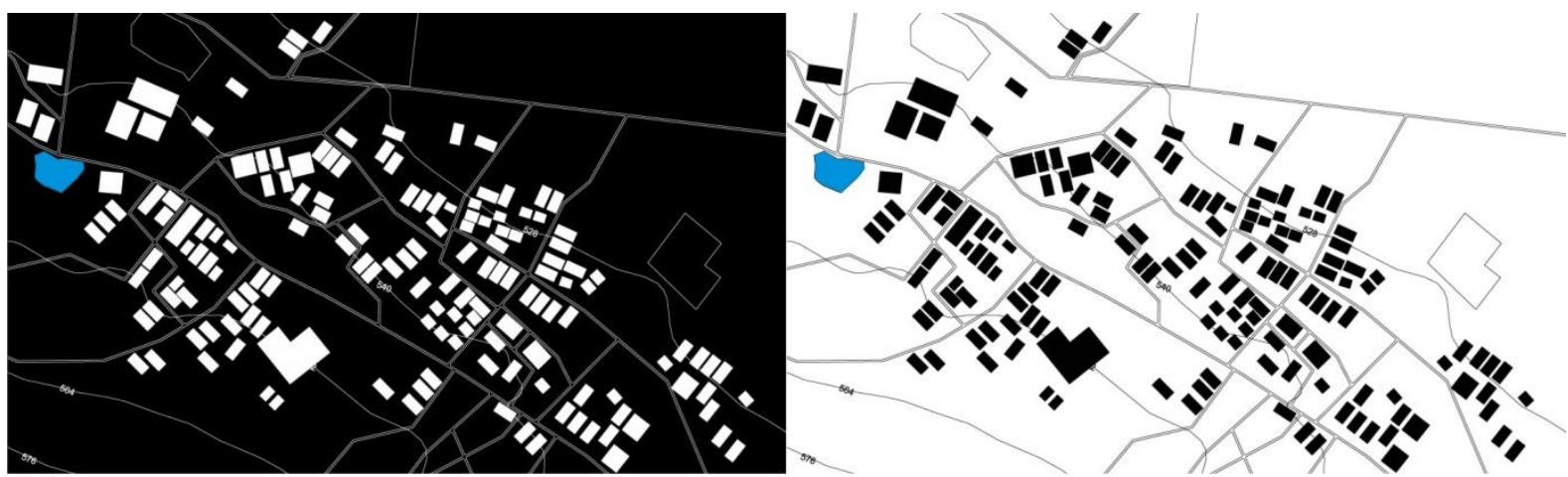

Gambar 14. Solid Void dengan Massa Bangunan Rata-rata Satu Lantai Sumber: Data yang diolah, 9 Oktober 2015

\subsubsection{Building Structures (Tipe dan Massa Bangunan)}

Terdapat lahan antar bangunan yang secara tidak sengaja membentuk ruang sebagai open space. 
Tipe bangunan yang ada di Desa Polaman memiliki pola yang menyebar dengan bentuk bangunan rumah sederhana tradisional. Hal ini menjadi ciri khas rumah di pedesaan. Struktur konstruksi bangunan rumah penduduk sebagian besar menggunakan bahan yang sederhana karena mereka banyak yang hidup sebagai petani, sehingga untuk tempat tinggal mengambil bahan yang murah, karena penuduk umumnya mengutamakan fungsi pokok dari rumah adalah untuk bernaung dan bukan untuk ditonjolkan.

\subsubsection{Plot Pattern (Pola Kapling)}

Kapling secara fisik dalam perkembangannya bisa mengalami perubahan bentuk. Adapun perubahan bentuk tersebut melalui proses pembagian, pemisahan, perpindahan, penghapusan dan pertukaran, penambahan dan pengurangan.
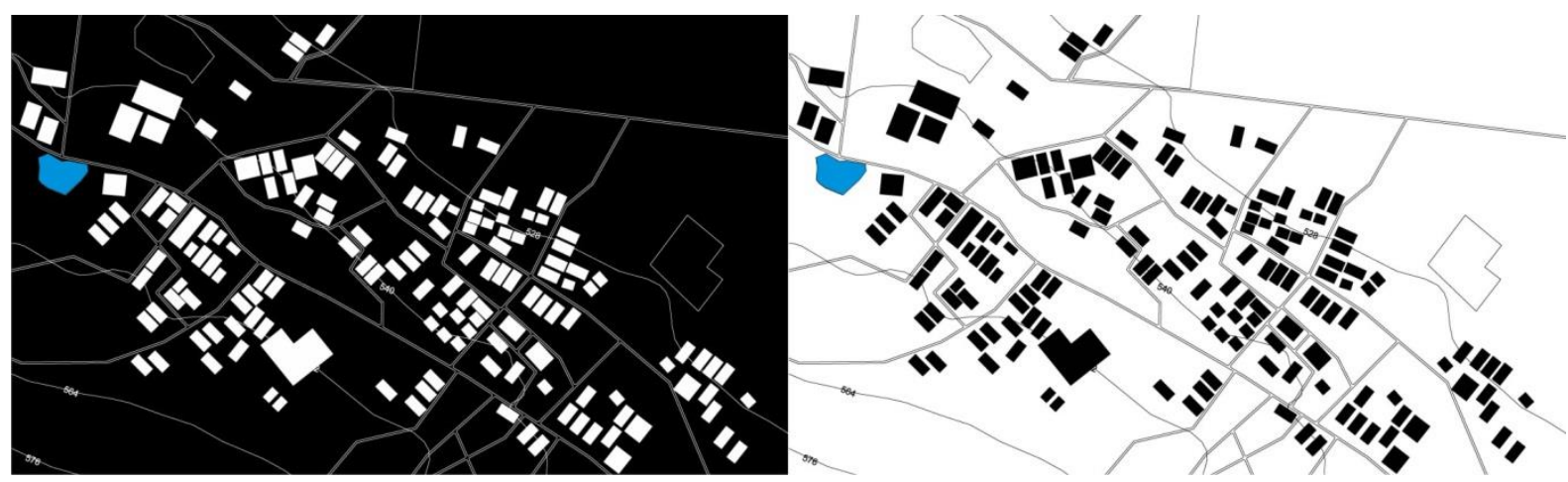

Gambar 15. Tatanan Massa Bangunan Menyebar dan Berkelompok Mengikuti Pola Aliran Sungai, Orientasi Bangunan Menghadap Jalan

Sumber: Data yang diolah, 9 Oktober 2015

Tatanan massa bangunan pada lokasi kelompok rumah umumnya berdasarkan kekerabatan. Desain arsitektur meniru atau mengikuti rumah tetangganya yang dianggap cocok dan sesuai jaman, atau sesuai dengan dana yang dimiliki. Material yang digunakan mengikuti material yang umum digunakan pada masanya. Tatanan massa bangunan pada lokasi kelompok rumah umumnya berdasarkan kekerabatan. Karakteristik kawasan permukiman penduduk perdesaan ditandai terutama oleh ketidakteraturan bentuk fisik rumah. Hal ini terjadi pada pola permukiman Desa Polaman, masih cenderung berkelompok membentuk perkampungan dan letaknya memang tidak jauh dari sumber mata air Polaman. Bentuk fisik rumah tidak teratur. Selain itu pola permukimannya masih sangat tradisional, banyak mengikuti pola aliran sungai, karena sungai di samping sebagai sumber kehidupan sehari-hari juga berfungsi sebagai jalur transportasi antar wilayah.

Pola keruangan desa yang ada di Polaman Lawang mempunyai dua jenis, yaitu:

A. Memanjang jalan: Susunan desanya mengikuti jalur-jalur jalan dan sungai.

B. Memanjang sungai: Susunan desanya mengikuti jalur-jalur jalan dan sungai.

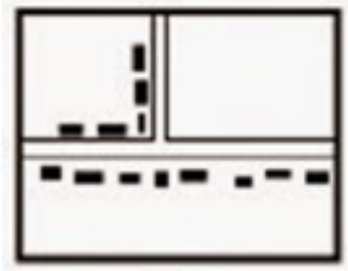

A

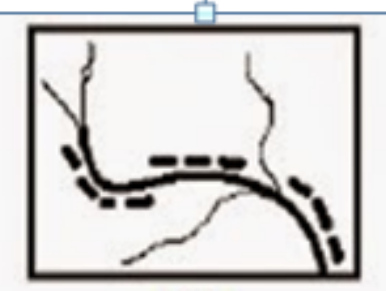

B

Gambar 16. Pola Keruangan Desa 


\subsubsection{Street Pattern (Pola-pola Jalan/Sirkulasi)}

Sirkulasi merupakan elemen yang sangat penting dalan lansekap, karena menentukan hubungan anatara permukiman penduduk dengan kolam Polaman menuju ke tempat atau lokasi lain. Akses jalan utama berupa aspal dibuat dua jalur untuk kendaraan bermotor. Akses menuju kampung berupa gang, ada dua macam perkerasan, dengan paving dan jalan makadam atau bebatuan.

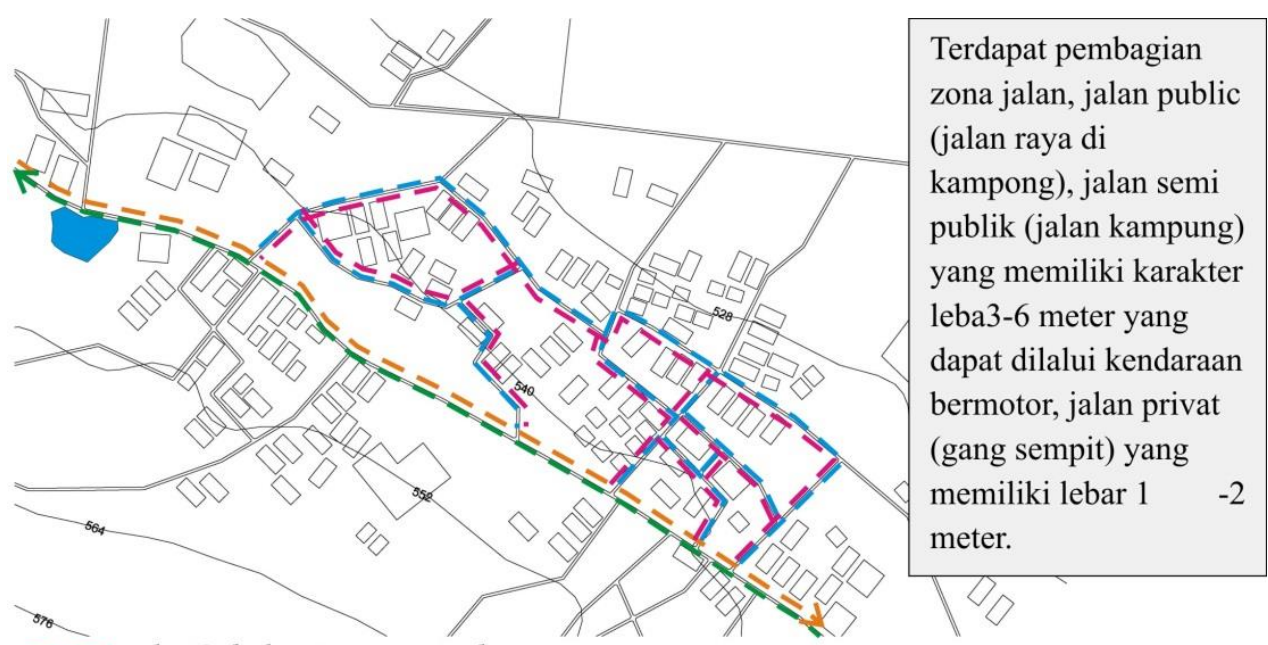

$==$ : Jalur Sirkulasi Utama 2 Arah

$==$ : Jalur Sirkulasi Kampung 2 Arah
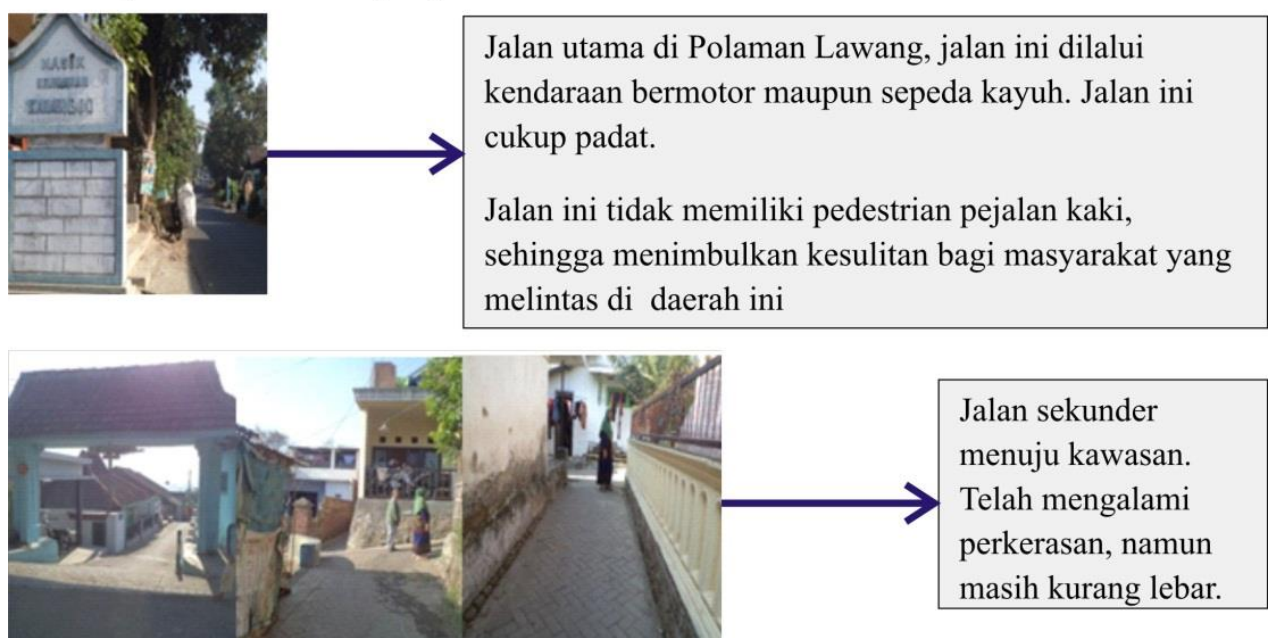

Gambar 17. Akses Jalan Utama dan Jalan Menuju Kampung Padat Desa Polaman Lawang Sumber: Dokumentasi Pribadi, 9 Oktober 2015

Aksesibilitas jaringan jalan menuju lokasi rumah warga tumbuh secara natural dan merupakan kerjasama pemerintah dan swadaya masyarakat. Pola pertumbuhan jaringan jalan utama dan jalan kampung sejalan dengan tumbuhnya rumah yang dibangun. 


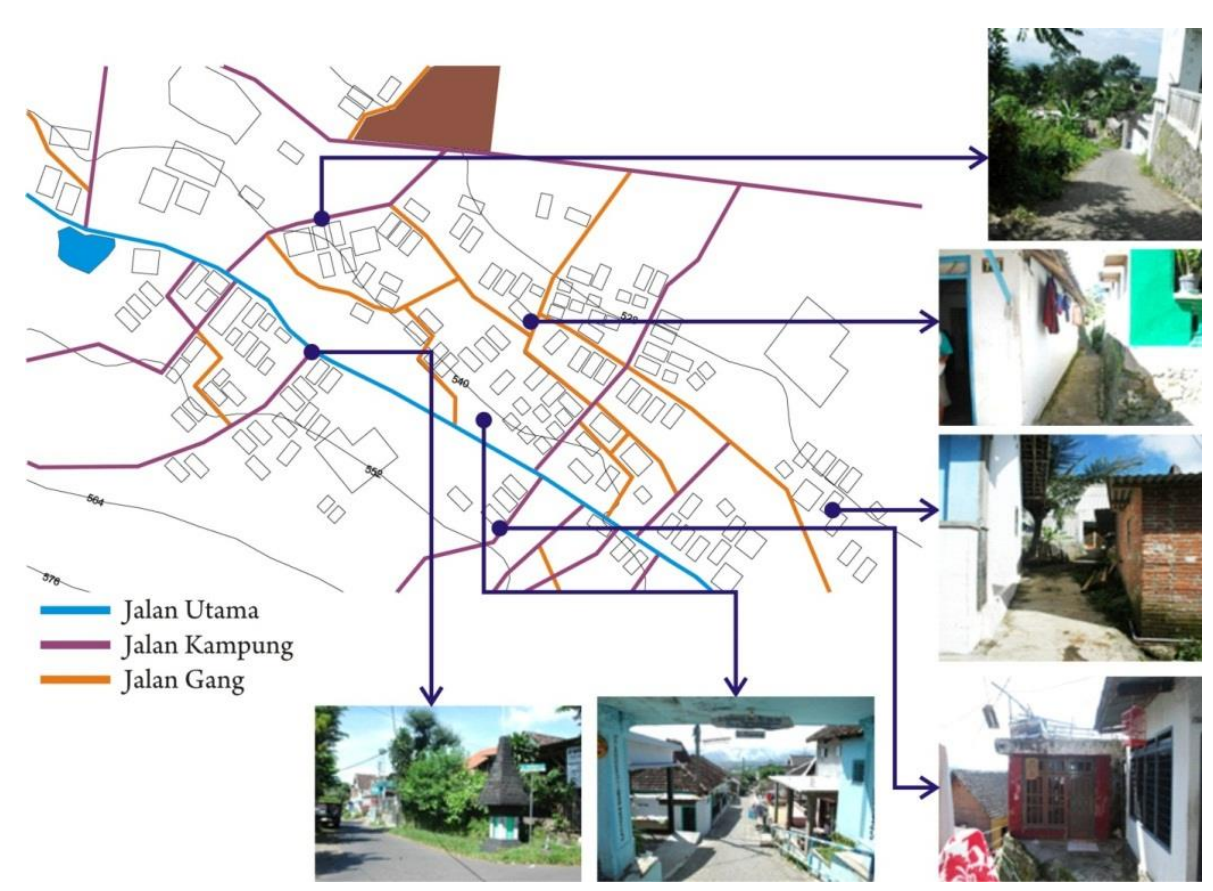

Gambar 18. Letak Jalan Utama dan Jalan Menuju Kampung Padat Desa Polaman Lawang Sumber: Dokumentasi Pribadi, 9 Oktober 2015

\subsection{Karakteristik Non-Fisik Elemen Pembentuk Kawasan Sumber Polaman Lawang}

\subsubsection{Bahasa}

Bahasa yang digunakan masyarakat dalam kehidupan sehari-hari adalah Bahasa Jawa. Dimana tatanan bahasa Jawa ngoko yang lebih sering digunakan daripada karma inggil. Hal ini disebabkan masyarakat usia muda sudah tidak lagi menggunakan Bahasa Jawa yang sesuai dengan aturan penggunaan Bahasa Jawa asli.

\subsubsection{Mata Pencaharian}

Mata pencaharian mayoritas penduduk Desa Polaman adalah petani, peternak dan buruh pabrik. Lahan persawahan yang masih sangat luas dan subur ditanami padi. Sedangkan ada beberapa lahan yang digunakan sebagai lahan pertanian sayuran. Hasil dari pertanian dan peternakan ini digunakan masyarakat desa untuk memenuhi kebutuhan hidup sehari-hari.

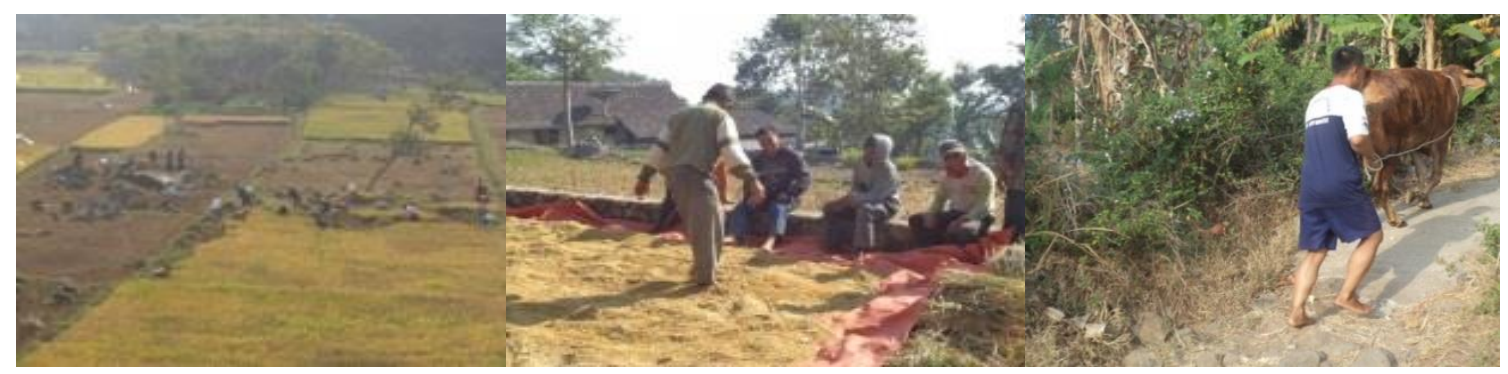

Gambar 19. Tampak Masyarakat sedang Memanen Hasil Pertanian Mereka Sumber: Dokumentasi Pribadi, 9 Oktober 2015

\subsubsection{Organisasi Sosial dan Religi}

Sosial budaya masyarakat di Desa Polaman, Lawang masih sangat kental dengan budaya ritual keagamaan yang selalu dilakukan pada hari dan tempat tertentu misalnya sholat Jumat berjama'ah, tahlilan atau pun pengajian yang rutin dilakukan warga. Hal ini dikarenakan sebagian besar masyarakat Desa Polaman menganut Agama Islam, meskipun dalam pelaksanaan ritual-ritual tertentu masih bercampur dengan Budaya Kejawen. Kondisi 
masyarakat Polaman terlihat guyub dan aktif dalam kegiatan sosial seperti menjaga kampung secara bergantian (siskamling), kegiatan karang taruna dan kegiatan ibu-ibu PKK. Koentjaraningrat (1990), menyatakan bahwa solidaritas adalah suatu bentuk kerjasama pada masyarakat yang meliputi aktivitas gotong royong, tolong menolong dan musyawarah. Selain rasa kepatuhan yang didasarkan kepada perasaan moral, masyarakat juga mengenal seperangkat nilai yang intinya memupuk rasa solidaritas atau disebut nilai yang mempersatukan (assosiatif) yang mempunyai butir-butir positif yaitu persaudaraan, kekeluargaan, kerukunan dan kegotong-royongan.

\subsection{Pola Ruang Budaya Tradisi Barikan desa Polaman}

Ditinjau dari intensitas penggunaannya, ruang dapat dibagi menjadi tiga, yaitu:

1. Ruang aktif

2. Ruang setengah aktif

3. Ruang pasif

Bentuk dan ruang tergantung pada persepsi seseorang terhadap batas-batas spasial yang didefinisikan oleh elemen-elemen bentuk. Ketika ruang mulai dirasakan dan terbentuk oleh elemen-elemen massa maka saat itulah arsitektur hadir.

\subsubsection{Ruang Sosial (Social Space)}

Tidak berbeda dari definisi ruang, Rapoport (1973) dalam kajian arsitektur lingkungan dan perilaku mengungkapkan pengaruh ruang terhadap perilaku manusia, yaitu fungsi/pemakaian dari ruang tersebut dirancang untuk memenuhi fungsi yang fleksibel. Masih menurut Rapoport (1977) proses interaksi sosial sebenarnya terjadi pada daerah dengan batas kepentingan pribadi (personal space) dengan publik yang biasanya dilakukan pada daerah yang disebut sosial space. Personal space sifatnya sangat relatif, artinya tergantung tempat dilakukannya hubungan sosial yaitu semakin banyak kelompok orang yang berinteraksi dalam suatu ruang maka jarak personal space semakin sempit.

Ruang sosial terbagi menjadi tiga tipe, yaitu:

1. Lingkungan pengenalan sosial

2. Lingkungan yang mempunyai kesamaan

3. Lingkungan perumahan

\subsubsection{Ruang Budaya (Cultural Space)}

Kebudayaan adalah hasil karya manusia dalam usahanya mempertahankan keturunan dan meningkatkan taraf kesejahteraan dengan segala keterbatasan kelengkapan jasmaninya serta sumber-sumber alam yang ada disekitarnya. Kebudayaan juga dapat dikatakan sebagai perwujudan tanggapan manusia terhadap tantangan yang dihadapi dalam proses penyesuaian diri mereka dengan lingkungan baik sebagai makhluk biologis maupun makhluk budaya. Kultural (budaya) adalah hasil kegiatan dan penciptaan batin ataupun akal budi manusia seperti kepercayaan, kesenian dan adat istiadat serta keseluruhan pengetahuan manusia sebagai makhluk sosial yang digunakan untuk memahami lingkungan serta pengalamannya dan dijadikan sebagai pedoman.

Upacara adat yang secara rutin dilakukan penduduk setempat yaitu acara "Barikan". Upacara ritual ini diadakan setiap Jum'at Legi yaitu setelah melaksanakan sholat Jum'at di masjid terdekat. Kegiatan ini diikuti oleh warga RT 03 dan RT 04, RW 10 tepatnya di Gang Teratai 3. Tujuan diadakannya ritual barikan ini adalah memohon kepada Tuhan yang maha kuasa supaya penduduk polaman diberikan rejeki yang berlimpah, selamat dari marabahaya. Upacara ritual barikan hanya dilakukan oleh warga dua RT tersebut, karena makam Desa 
Karang Suwung masih merupakan wilayah RT 03 dan RT 04. (Observasi lapangan, 9 Oktober 2015).

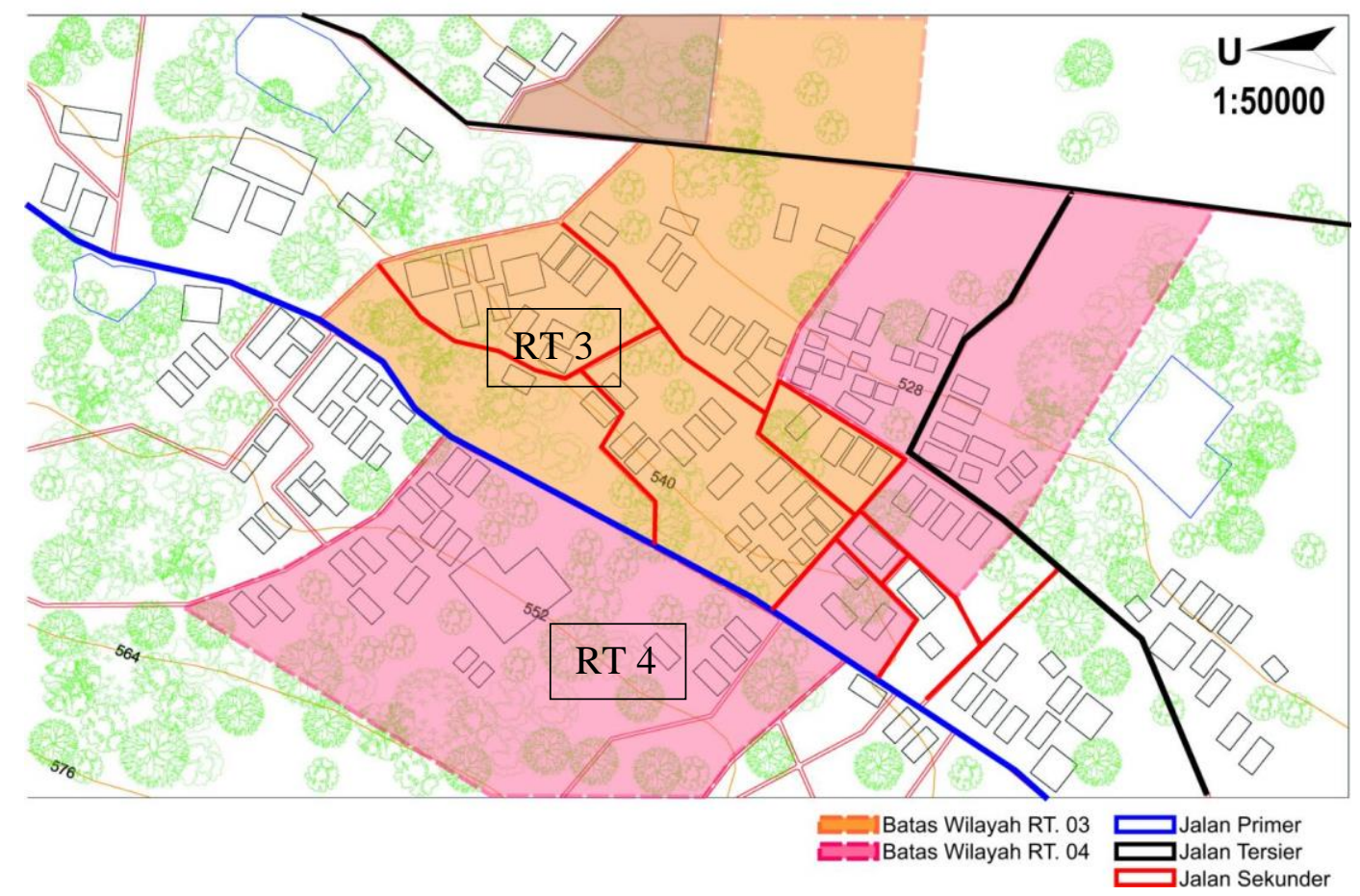

Gambar 20. Peta Batas Wilayah RT 03 dan RT 04, RW10 Desa Polaman Sumber: data yang diolah dan Google Maps, 2013

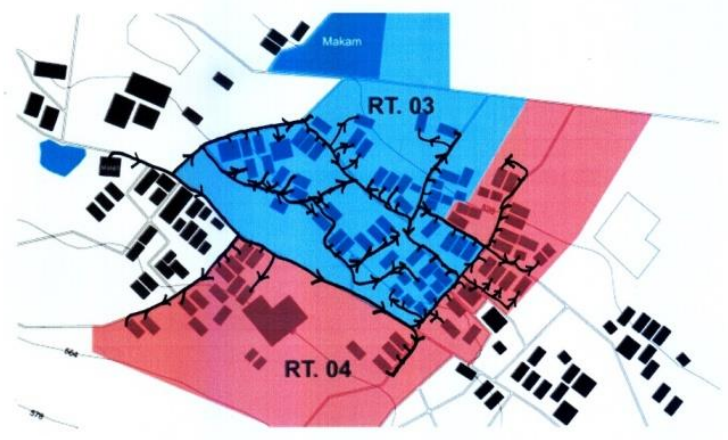

Pola Sirkulasi deri Hasjid meruju rumatr masing untuk tmengambil sesejem.

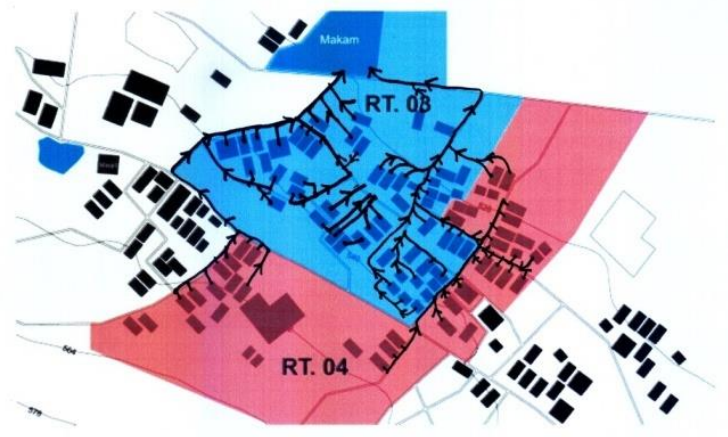

Pola Sirkulasi dari rurtate masing $\frac{2}{2}$ warga menuju makamdesa. Sambil membawa sesajen.

Gambar 21. Gambar Pola Sirkulasi Acara Ritual Barikan di Desa Polaman Sumber: Observasi Lapang, 2015

\section{Simpulan}

Dalam arsitektur, ruang tidak hanya berarti fisik saja dan tidak begitu saja lahir tanpa pemahaman ruang dan elemen lain yang berhubungan seperti kondisi sosial budaya maupun kejiwaan dalam hubungan antar individu dan dengan lingkungannya. Bentuk dan ruang tergantung pada persepsi seseorang terhadap batas-batas spasial yang didefinisikan oleh elemen-elemen 
bentuk. Ketika ruang mulai dirasakan dan terbentuk oleh elemen-elemen massa maka saat itulah arsitektur hadir.

"Ruang Budaya" adalah ruang yang mewadahi aktivitas kebiasaan hidup masyarakat di suatu komunitas sebagai cerminan budaya, tradisi, ritual keagamaan dari masyarakatnya. Toleransi ruang yang terjadi adalah berkaitan dengan kebutuhan manusia sebagai makhluk sosial yang membutuhkan interaksi dengan manusia lainnya dan lingkungan tempat tinggalnya. Di Desa Polaman, masyarakatnya masih melaksanakan ritual adat Barikan . Ruang budaya terbentuk dengan adanya kegiatan tersebut yang dilakukan secara rutin oleh masyarakat Polaman.

\section{Daftar Pustaka}

Ardianti, Intan, Antariksa, Wulandari, Lisa Dwi. 2014. Teritorial Ruang Sosial Budaya pada Permukiman Etnis Madura-Hindu Dusun Bongso Wetan Gresik. Prosiding Seminar Nasional Arsitektur Pertahanan 2014, Insting Teritorial dan Ruang Pertahanan, ISBN 978-60271099-0-2.

Carmona. 2003. "Public Space Urban Space" The Dimention of Urban Design. London: Architectural Press London.

Cresswell, Jhon W., (2012). Educational Research: Planning, Conducting, and Evaluating Quantitative and Qualitative Research. Ney Jersey: Person Education, Inc.

Indeswari, Ayu, Antariksa, Pangarsa, Galih Widjil, Wulandari, Lisa Dwi. 2013. Pola Ruang Bersama pada Permukiman Madura Medalungan di Dusun Baran Randugading. Jurnal RUAS, Volume 11 No.1, Juni 2013. ISSN 1693-3702.37.

Iswadi, Slamet. 2012. Sumber Air Polaman. Dalam http://mlebulawang.blogspot.com. Diakses tanggal 30/09/2015.

Koentjaraningrat. 1990. Sejarah Teori Antropologi II. Jakarta: UI Press.

Laurens, J.M. 2004. Arsitektur dan Perilaku Manusia. Jakarta: PT. Grasindo.

Nasir, Mohammad. 1999. Metode Penelitian. Jakarta: Ghalia Indonesia.

Norberg-Schulz, C. 1979. Genius Loci. New York: Electa/Rizolly.

Prasasti, Shinta. 2015. Wilayah Lawang di Masa Klasik. Dalam www.Prasastishinta.blogspot.com. Diakses tanggal 16/10/2015.

Putro, Anjar. 2014. Kecantikan Alam Polaman, Misteri dan Sejarah. Dalam www. acaraapa.com. Diakses tanggal 30/09/2015.

Rapoport, A. 1977. Human Aspect of Urban Form, Towards a Man- Environment Approach to Urban Form and Design. New York: Pergamon Press.

Rapoport, A. 1969. House, Form and Culture. New York: Prentice Hall.

Sasongko, Ibnu. 2005. Pembentukan Struktur Ruang Permukiman Berbasis Budaya (Studi Kasus: Desa Puyung - Lombok Tengah). Jurnal Dimensi Teknik Arsitektur Vol. 33, No. 1, Juli 2005: $1-8$.

Sugiyono. 2006. Metode Penelitian Kuantitatif Kualitatif dan R\&D. Bandung: Alfabeta.

Sutopo. 2006. Metodologi Penelitian Kualitatif. Surakarta: UNS.

Tuan, Yi-Fu. 1977. Space and Place, The Anthropology of Architecture in South-Esat Asia. Singapore: Kyodo Printing.

Warsito, Hermawan. 1992. Pengantar Metodologi Penelitian: Buku Panduan Mahasiswa. Jakarta: Gramedia Pustaka Utama.

Wurianto, Arif Budi. 2009. Aspek Budaya pada Upaya Konservasi Air dalam Situs Kepurbakalaan dan Mitologi Masyarakat Malang. HUMANITY, Volume IV, Nomor 2, Maret 2009, Hal. 80-88 